\title{
Gastroesophageal Junction Large Cell Neuroendocrine Carcinoma
}

National Cancer Institute

\section{Source}

National Cancer Institute. Gastroesophageal Junction Large Cell Neuroendocrine

Carcinoma. NCI Thesaurus. Code C126323.

An aggressive, high-grade and poorly differentiated carcinoma with neuroendocrine

differentiation that arises from the gastroesophageal junction. It is characterized by the presence of malignant large cells. 